\title{
走査振動電極の腐食疲労への適用*
}

\author{
柴田俊夫**, 藤本慎司** \\ ** 大阪大学工学部治金工学科
}

\section{Application of the Scanning Vibrating Electrode Technique to Corrosion Fatigue*}

\author{
Toshio Shibata** and Shinji Fujimoto** \\ Metallurgical Engineering, Faculty of Engineering, Osaka University
}

\begin{abstract}
A scanning vibrating electrode system is developed for the analysis of corrosion fatigue of a high strength steel in synthetic sea water. The distribution of current density on the specimen during corrosion fatigue test is measured and displayed in a 3-dimensional map. It is found that local anodic current is observed at the main fatigue crack. However, most of anodic currents are observed in the area covered by corrosion products, under which many small pits associated with micro cracks are found. It is concluded that not only the main fatigue crack but also micro cracks formed under corrosion products contribute to the anodic current which determines the corrosion potential during corrosion fatigue process.
\end{abstract}

\section{1. 緒言}

腐食環境に拈ける疲労損傷 ${ }^{1)}$ は亀裂発生及び亀裂伝播 の双方に腐食反応が関与すると考えられる。近年, 亀裂 進展過程の破壊力学的取り扱いに関心がもたれている が，正確な寿命評価のためには亀裂の発生条件の解明も 極めて重要である。腐食疲労の場合には，金属表面での 局部腐食が亀裂発生に関与していると考えられる。実際 の環境での腐食疲労損傷に拈いては, 亀裂発生までの時 間が亀裂進展時間よりはるかに長く，寿命を支配する場 合が多いため, 亀裂発生に至る局部腐食の挙動を知るこ とは極めて重要である。一方, 亀裂伝播中においての亀 裂先端及び他の部分にて進行する腐食反応, すなわら電 気化学反応過程の役割は必ずしも明らかでない。例えば 本報告にて扱う, 海水中での鋼の腐食疲労の場合, 亀裂 先端にて起こっている反応がアノード溶解によって支配 されているのかあるいは水素発生に伴う水素脆化なのか は必ずしも明確には示されていない。さらに，これまで に行われている繰り返し荷重下での分極測定等の電気化 学測定では試料全体の挙動を観察しているので現実に起

* 第 32 回腐食防食討論会で発表 (1985. 8 於 札幌).

** 干565 吹田市山田丘 2-1 (2-1 Yamada-oka, Suita, 565 Japan).
こっている局在化したアノード，カソード両反応を分離 して評価することはできない。また分極することにより 系を乱していることになり好ましい測定法ではない。

本報告では金属表面にて進行している局部腐食の分布 を評価するために走査振動電極システムを開発し，腐食 疲労進行中の金属材料表面の腐食反応分布の追跡 ${ }^{2)}$ を行 ない,アノード及びカソードの両反応の腐食疲労への奇 与を検討した結果について述べる。

\section{2. 実 験}

\section{1 走査振動電極システム}

\subsection{1 測 定原理}

局部電池形成によって腐食反応が進行している金属表 面付近の溶液内には反応に関与するイオン電流の IR 降 下による電位勾配が存在する。この電位勾配の大ささは 電流密度に比例するので, 従来はわずかな間隔を括いた 2 つの微小電極によって 2 点間の電位差を測定すること により，この間の電位勾配を求めることが行われてい $た^{3), 4)}$ この方法では微小な電位差をバックグランドノ イズから分離するのが困難なため腐食速度の大きい系, あるいは IR 降下の大きな希薄溶液を用いる場合などに 適用範囲が限定されていた。ところで微小電極に喠敉橴 

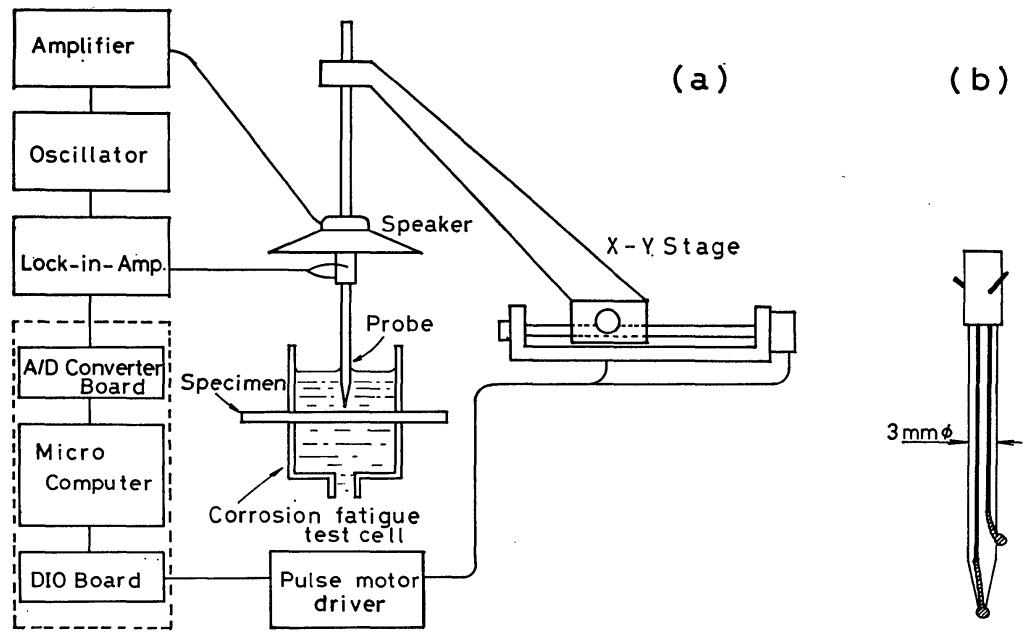

Fig. 1 Schematic drawning of the scanning vibrating electrode system and (b) $\mathrm{Ag} / \mathrm{AgCl}$ vibrating electrode.

を与えることにより，この電位勾配に比例した振幅の交 流信号を得ることができる。これによってロックインア ンプの使用が可能となり， $\mathrm{S} / \mathrm{N}$ 比が飛躍的に向上するた め極めて小さな電流密度の測定が可能となった。この方 法は当初生体内に拈ける微小なイオン流の検出のために 開発された 腐食の検出飞応用 ${ }^{6)}$, 7) した。すなわち，この振動電極を 金属表面上で前後左右に走查することによりアルミニウ 么の孔食の発生, 成長に伴ら局部電流の分布が測定され た。この手法の特徵は微小な電流密度分布を, 被測定系 になんら影響を与えずに測定可能なことにある。

\subsection{2 装置の構成}

Fig. 1(a) に本研究にて用いた装置の概略8を示す。 本システムは電位検出系, 振動発生系, プローブ走查系 及び制御，記録系（マイクロコンピューター等）より構 成される。電位測定プローブは $0.2 \mathrm{~mm} \phi$ の $\mathrm{Ag}$ 線の 先端を熔融して形成した直径約 $0.5 \mathrm{~mm} の \mathrm{Ag}$ チップ を Fig. 1(b) のように $3 \mathrm{~mm} \phi$ のガラス管に取りつけ た。これを希塩酸中でアノード処理することにより $\mathrm{Ag} /$ $\mathrm{AgCl}$ 電極とした。試験溶液が一定濃度の塩素イオンを 含む場合には，溶存酸素濃度の変化等の酸化/還元系の 影響を受けずに安定な電位を示す。2 個の電極のうち, 試料より離れた方は測定に直接関与しない参照極であ る。従って, 試料表面での腐食による電位変化の影響を 受けない高さに設置してある。二つの塩化銀電極からの リード線はロックインアンプに入力される。微小電極に 綐振動を与えるために, 本システムでは小型スピーカー を用いた。オシレーターの出力を低周波増幅器にて増幅 し，スピーカーを駆動することによって電極浽緃振動を 与光る。また, オシレーターの出力はロックインアンプ
の参照入力ともなる。試料表面と電極先端との距離は近 い程, また縦振動の変化は小さい程空間的分解能は向上 するがノイズの除去めるいは電極の加工及び電極設置位 置の制御は難しくなる。本研究にて取り扱ら海水中の高 張力鋼の局部腐食の場合あまり分解能が必要でないこと がわかったので, 電極と試料間の距離は $0.3 \sim 0.5 \mathrm{~mm}$, 振幅は約 $300 \mu \mathrm{m}$ また振動数は $100 \sim 150 \mathrm{~Hz}$ とした。 電極の走査はパルスモーターにて駆動されるX-Y ステ ージにて行った。ロックインアンプの出力の取り込み及 び X-Y ステージの制御はマイクロコンピュータにて行 った。測定は，走查電極を原点よりX方向へ，あらかじ め設定した一定距離進むごとに停止し，ロックインアン プの出力をサンプリングする。設定領域の端に達すれ ば，Y 方向へ一定距離進み，次に $-\mathrm{X}$ 方向へ進む。この 走査を繰り返して設定される領域の走查を終われば原点 に戻り測定は終了する。データは走查終了後にフロッピ ーディスクに格納される。電極の走査のシーケンス等は プログラムにより自由に設定可能である。走査のステッ プは最小 $2.5 \mu \mathrm{m}$ の間隔に制御できる。

測定された電位差の電流密度への換算は溶液の電導度 及び電極の縦振動の振幅が既知であれば計算により求ま るが, 本研究に捯いてはあらかじめキャリブレーション により装置定数を求めることによって変換した。その結 果, 本装置を用いて, $1 \mu \mathrm{A} / \mathrm{cm}^{2}$ 以下の微小電流密度の 検出が可能であることが明らかとなった。

電流密度分布の表示は $X-Y$ 平面に位置を， $Z$ 軸を電 流密度とした 3 次元プロットをコンピューターグラフィ ックスにより作成した。

\section{2 腐食疲労試験}

本研究にて用いた試料は高張力鋼 HT-50 及び HT-60 
Table 1 Chemical composition of high strength steels. (mass \%)

\begin{tabular}{ccccccccccc}
\hline \hline Steel & $\mathrm{C}$ & $\mathrm{Si}$ & $\mathrm{Mn}$ & $\mathrm{P}$ & $\mathrm{S}$ & $\mathrm{Cu}$ & $\mathrm{Ni}$ & $\mathrm{Cr}$ & Mo & $\mathrm{Fe}$ \\
\hline HT-50 & 0.15 & 0.44 & 1.42 & 0.009 & 0.001 & 0.27 & 0.19 & - & - & bal. \\
HT-60 & 0.12 & 0.30 & 1.26 & 0.014 & 0.002 & 0.49 & 0.15 & 0.12 & 0.15 & bal. \\
\hline
\end{tabular}

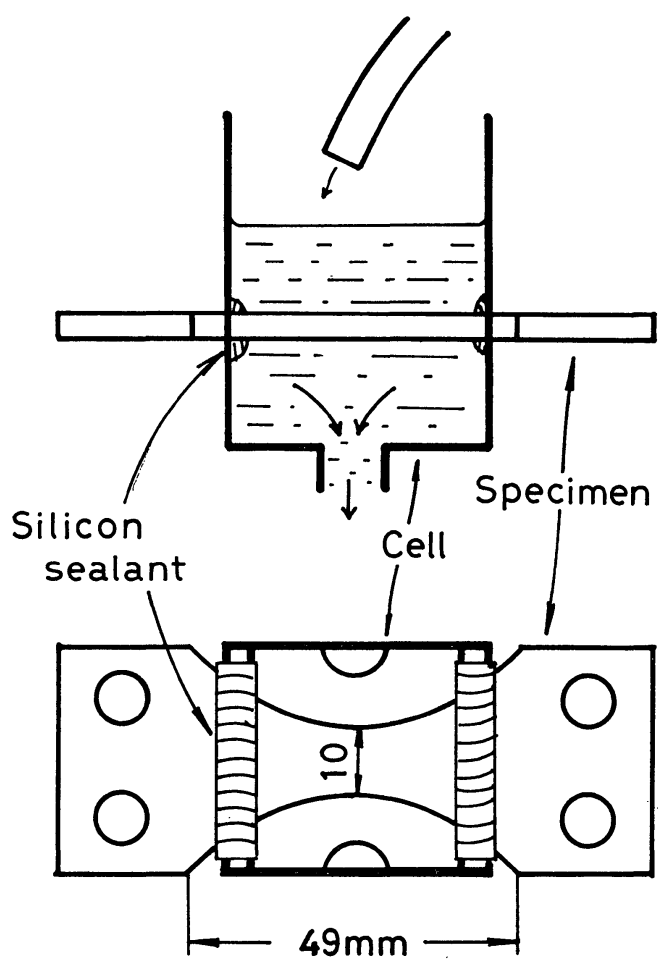

Fig. 2 Corrosion fatigue test specimen and test cell.

の平面曲げ標準試験片である。これらの化学組成を Table 1 に示した。試験片及びアクリル製腐食セルの形 状を Fig. 2 に示す。腐食液には人工海水 ((株) 八州薬 品製, アクアマリン, $\mathrm{pH}=8.2)$ を用い, 空気開放下に て $25^{\circ} \mathrm{C}$ に保って試片上側より注水, 循環させた。用い た試験機はシェンク 式平面曲げ疲労試験機 $(1750 \mathrm{cpm})$ である。すでに述べたように，走査振動電極による測定 は微小電極を試料の表面近傍にて走査するために大きな 上下変位を繰り返している疲労試験中の試料の測定は不 可能である。従って, 走査電極による測定は, 疲労試験 ごと開始後 $30 \sim 100$ 分ごとに疲労試験を停止中断し,

Fig. 2 に示したよらに試料上側にて電極プローブを走査 させた。測定範囲は試料上面中央部分の $10 \times 10$ ないし $15 \times 10 \mathrm{~mm}$ の範囲を $0.5 \mathrm{~mm}$ ごとに測定した。1 回の 走査測定に要する時間は $4 \sim 6$ 分である。

\section{3. 実験 結 果}

\section{1 走査振動電極による測定例}

Fig. 3 (a) に示したよらな SUS 430 鋼に半田を埋め 込んだ試料を, 人工海水中にて腐食させたモデル孔食の 電流密度の分布を Fig. 3 (b), (c) に示す。この図で山 の部分が局部アノードであり, 電流密度 0 の平面より下 になっている部分はカソードである。

次に本研究で疲労試験の試料とした HT-50 鋼が人 工海水中にて局部腐食を生じる様子を Fig. 4 に示す。 Fig. 4 (a)〜 (f) はそれぞれ浸漬後 2.5, 3, 4.5, 7, 8, 及 び 24 時間後の電流密度分布を表示している。浸漬数時 間後に左端部分に孔食が発生し局部アノードとなり他の 部分はカソードとなっている。時間の経過に従い孔食が 成長するとともに溶け出した $\mathrm{Fe}^{2+}$ イオンが水酸化物 となって孔食周辺に沈殿するためにその下で溶解が起こ り局部アノード部分が広がっている。一方, アノード電 流の増大に対応してカソード電流も増大するとともに局 部カソードにも不均一が生じる。長時間の後には溶解が 抑制され全体的に電流密度は小さくなる。

この例が示すように, 高張力鋼は海水中で孔食の生成 及び沈殿性の腐食生成物の付着のためにアノード，カソ ードの分離がおこることが明らかである。

\subsection{HT-50 の腐食疲労寿命}

HT-50 及び HT-60 の空気中及び人工海水中での平面 曲げ疲労試験の結果を Fig. 5 に示す。空気中では疲労 限が存在し, さらに両鋼種間の差が見られる。一方, 人 工海水中では疲労限は認められず, また両鋼種間の差は ほとんど見られない。HT-50 と HT-60 は機械的強度に は差があるが腐食挙動には大差ないと考えられる。すな わち, このことは腐食疲労に拈いては力学的要因よりも 化学的要因が寿命を支配していることを示唆している。

なお，走査振動電極による測定は主に HT-50 につい て 250, 200 及び $150 \mathrm{MPa}$ のつの応力レベルにて行 った。

\section{3 腐食疲労試験中の腐食電位の変化}

Fig. 6 に示すように腐食疲労試験中の試料の自然電位 は荷重負荷開始直後より単調に下降する。この挙動は荷 重をかけずに試料に振動のみを与えた場合9) と同様であ る。ただし, 電位の值は荷重をかけている場合のほらが 約 $100 \mathrm{mV}$ 卑である。検討した範囲では荷重の大きさ の影響は明確ではないが荷重が大きい注ど卑な電位を示 す傾向が見られた。 


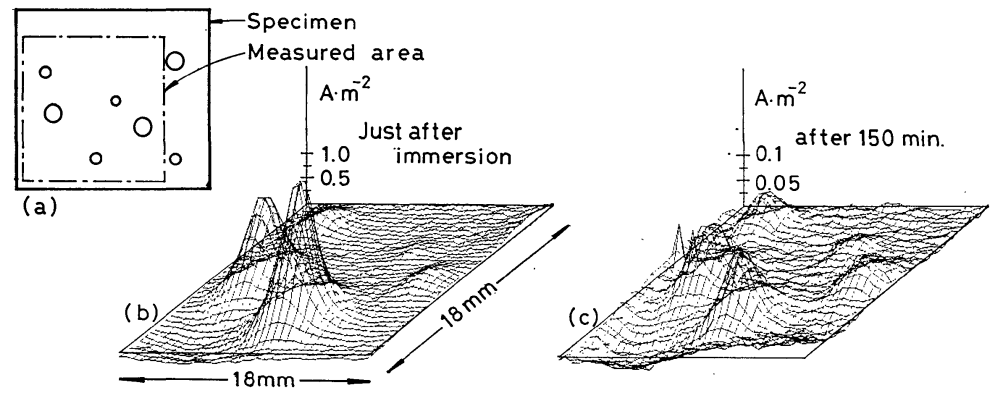

Fig. 3 An example of the 3-dimensional display of current density observed on a model pit; (a) SUS 304 stainless steel specimen with some spots filled with solder, (b) and (c) are current density distribution maps measured in synthetic sea water.

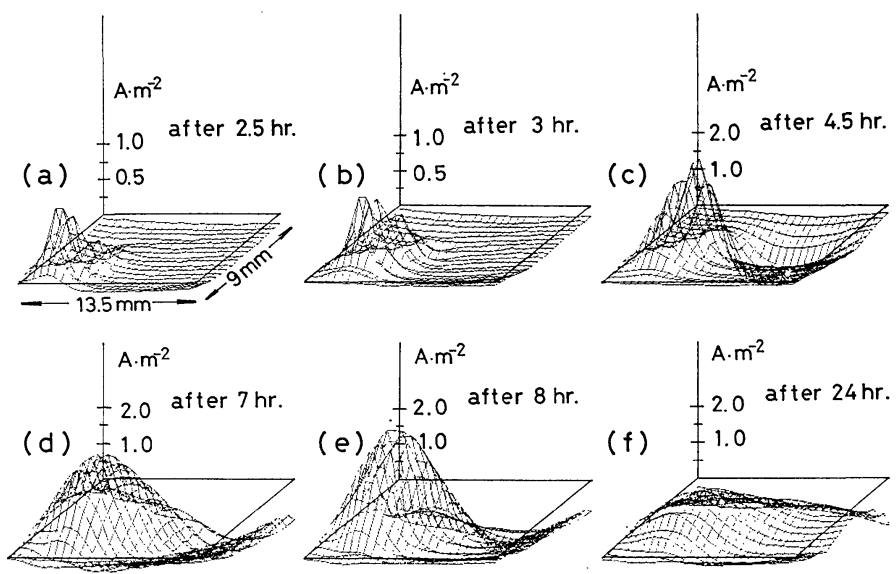

Fig. 4 Growth of a corrosion pit on HT-50 steel in synthetic sea water.

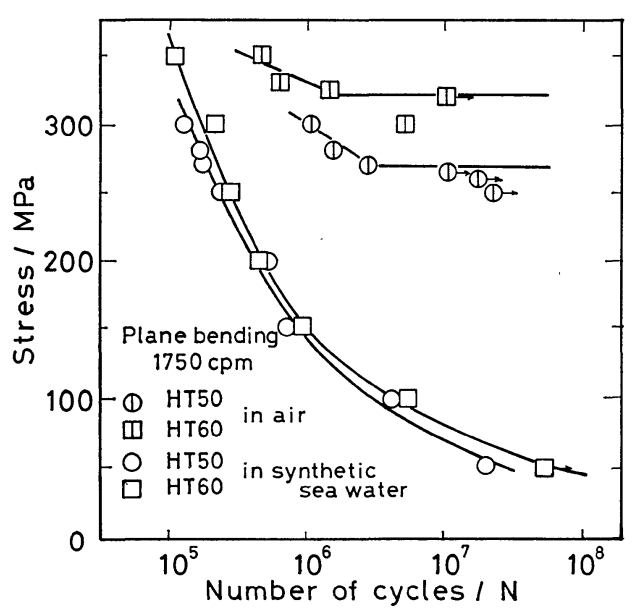

Fig. 5 S-N curves of HT-50 and HT-60 steels in air and in synthetic sea water.

\section{4 走查振動電極による 腐食疲労試験中の 試料表面 での電流密度分布}

走査振動電極による測定は疲労亀裂発生, 成長にとも

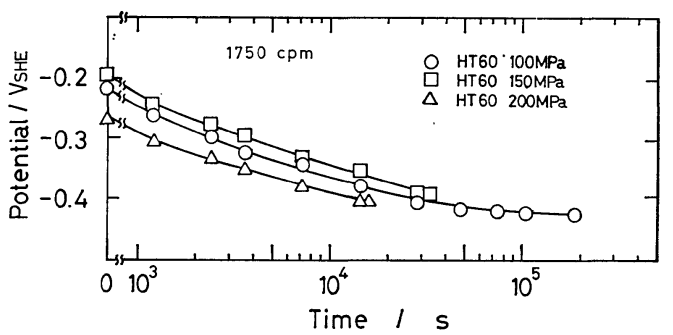

Fig. 6 Change in the corrosion potential with time during the corrosion fatigue test.

なら表面の腐食反応の分布を知ることを目的としてい る。この測定はプローブ及びセルの形状の都合より, 試 料上側面の中央部分のみ測定した。ところで, 疲労亀裂 は必ずしも試料上面から発生するのではないのでシリコ ン樹脂による被覆を行った。被覆の仕方により以下の 3 種類の試料を用いた。（A）被覆なし，（B）裏面被覆及 び (C) 裏面, 側面とも被覆。Fig. 7 に電流密度分布測 定の結果例を示す。これは, 荷重 $250 \mathrm{MPa}$, 試料 (B) で ある。な和，試片上の測定範囲及び亀裂発生位置を図中 

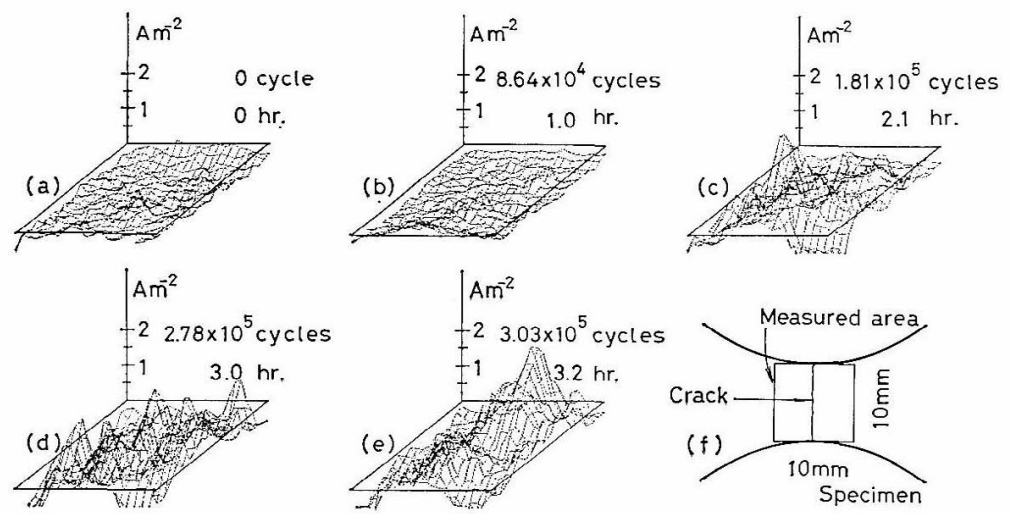

Fig. 7 Change in the distribution of the current density with time during the corrosion fatugue test (HT-50, $250 \mathrm{MPa}$ ), (f) shows the measured area and location of the crack.
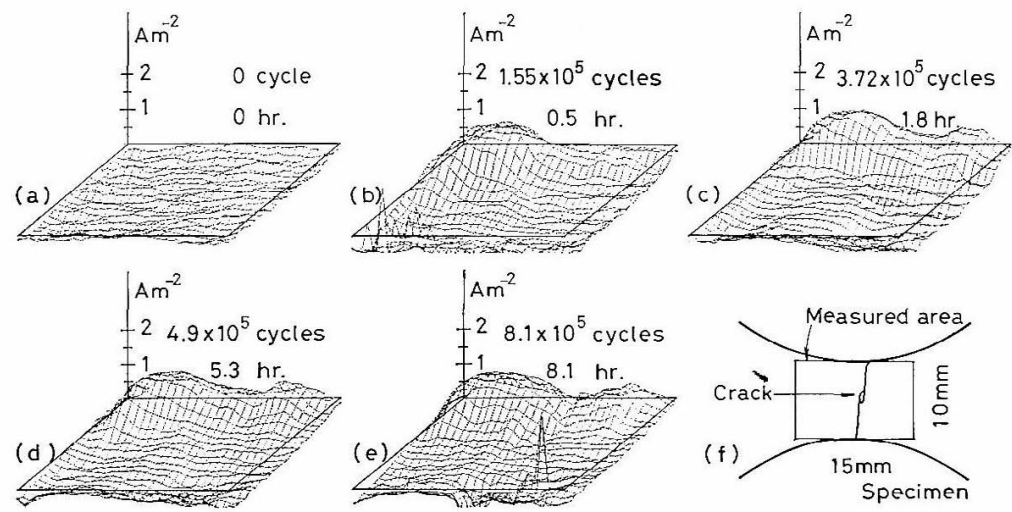

Fig. 8 Change in the distribution of the current density with time during the corrosion fatigue test (HT-50, $200 \mathrm{MPa})$.

に示す。(a)〜 (e) ほ時問の経過に従って和り, 荷重負荷 開始からの経過時間, 荷重繰り返し数はそれぞれの図中 飞記されている。荷重負荷開始直前 (a) では大きな局部 腐食は見られず，この測定範囲では全体的にカソードと なっている。(b) では手前中程に局部アノードが見られ (c)，(d) ではこれが明確に現われている。次に，Fig. 8

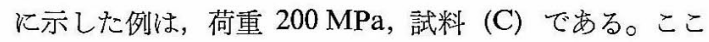
では，図の左上部にアノード域が見られるが中央部分に 発生した刍裂に対応するアノード電流は認め難い。Fig. 7 の例の上うに龟裂部分より大さなアノード電流が観測 されるのは高荷重の場合に限られる。多くの場合, 黾裂 開口部より集中してアノード電流が発生するのではな く, 表面上に腐食生成物の見られる場所が局部》ノ一 ドとなるようである。さらに，Fig. 8 (e) に見られるよ うに, 刍裂開口部で腐食生成物が取り除かれ，カッード となる場合も見られた。

\section{5 試験片の表面観察}

腐食疲労試験後の試片の SEM 観察の例を Fig. 9 K 示す。この写真の上半分は腐食生成物に覆われていた部

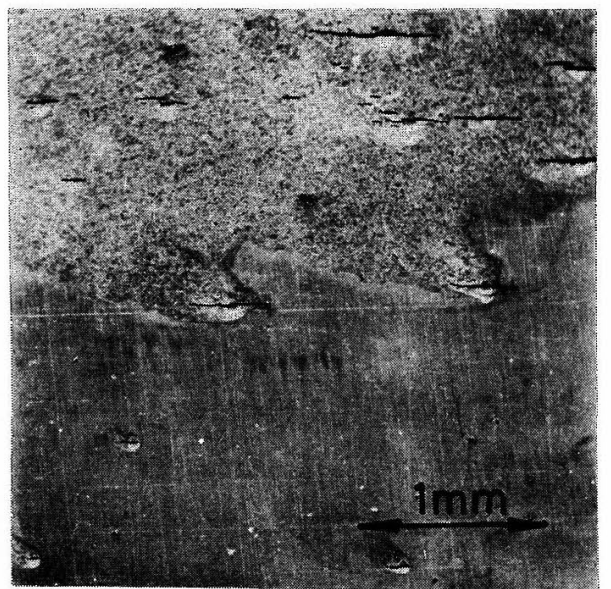

Fig. 9 Surface of the test specimen after corrosion fatigue test (HT-60, $150 \mathrm{MPa}$, raptured at $9.71 \times 10^{5}$ cycles).

分で、ここに多数の浅い半球状の孔食がみられここを起 点とする微小龟裂がみられる。このような腐食生成物 は，疝い範囲に分布して招り，SEM 観察の結果この部 


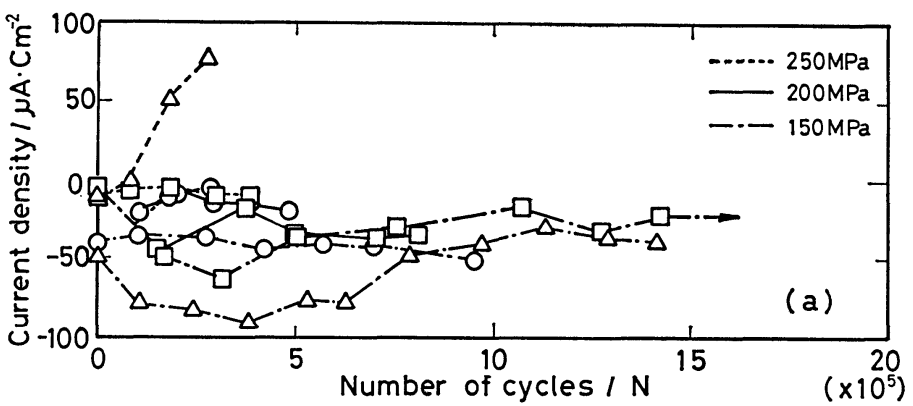

(a)

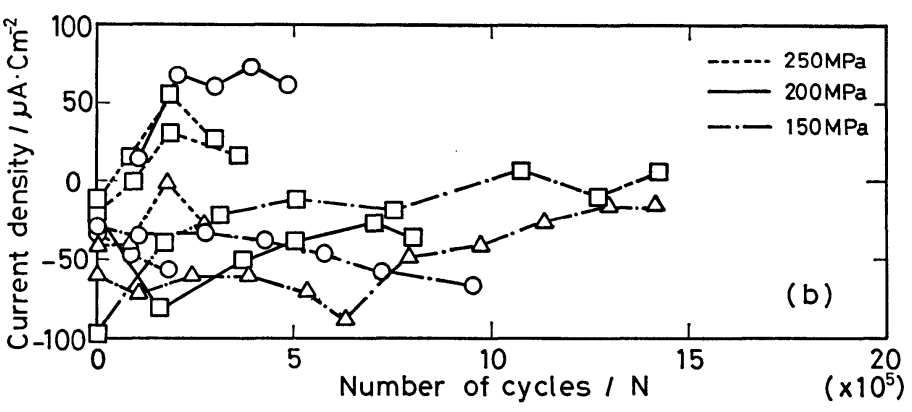

(b)

Fig. 10 Change in the current density at crack site with cycles of bending load, at (a) the edge and (b) the center of the specimen, respectively.

分に微小亀裂を伴ら孔食が分布している。

\section{4. 考察}

\section{1 亀裂部分での電流密度の 経時変化と 亀裂発生時 期との対応}

Fig. 8,9 では腐食疲労試験片の電流密度の分布につ いて述べたが，次に亀裂が発生し最終的に破断に至った 部分での電流密度の経時 (荷重繰り返し数の増加に伴う) 変化を整理する。亀裂部分での電流密度の荷重繰り返し 数の増加に伴ら変化を Fig. 10 に示す。Fig. 10 (a) は, 試料の端に近い部分，(b) は試料の中央部分での変化で

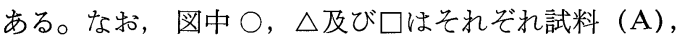
(B) 及び (C) の結果である。いずれの場合も腐食瘦 労試験開始前はカソードとなっている。これは側面，あ るいは被覆との境界などでアノード反応が起こっている ことに対応している。疲労試験開始後，高荷重である $250 \mathrm{MPa}$ ではアノード電流が直ちに増加した後にやや 減少し，その後破断に至る。一方，200，150 MPa では 電流密度はやや減少（カソード電流が増大）した後に再 びアノード電流の増大を示し，その後破断している。高 荷重の場合は, 荷重付加開始後腐食生成物を伴う孔食が 生成することなく直らに亀裂が発生するために，亀裂部 分からのみのアノード電流が測定されたと考えられる。 一方, 低荷重の場合は龟裂発生に至るまでに表面に水酸
化物を主体とする腐食生成物が不均一に沈殿し，この腐 食生成物に覆われている場所には Fig. 9 に示したよう に微小な孔食が多数認められる。すなわち，この部分で のアノード溶解は腐食生成物下の孔食にて優先的に起こ るが，この場所は主亀裂の発生する試料中央部分とは限 らず，むしろ試料とセルとの境界等のすきまを形成する 部分であることが多い。そのため，後に亀裂の発生する 部分は浸漬初期にはカソードとなっている。時間の経過 に従って腐食生成物の沈殿が試料中央付近にすで広がる と，その下での $\mathrm{pH}$ 低下のため多数の孔食が発生する が，繰り返し荷重が負荷されているために，この部分で の孔食は活性化されやすい。従って，アノード電流が増 大し始めたと考えられる。このように電流が増大し始め る時間と亀裂発生時期になんらかの対応があると考えら れる。Fig. 11 は S-N 曲線図中に, この時間に対応す る荷重繰り返し数を破線にて示した。これより，電流密 度が増大し始めるのは破断までの時間の $15 \sim 25 \%$ とな っている。亀裂発生時期は破断寿命の $10 \%$ 以下 ${ }^{10), 11)}$ と 言われており，やや遅い時間を示したが䈀発生時期に 関するなんらかの情報を得たものと考えられる。なお， この S-N 曲線の○， $\triangle$ 及びロのプロットは Fig. 10 と 同様にそれぞれ試料 (A)，(B) 及び (C) の結果である。 これより被覆の多いほうが破断繰り返し数が多いことが 分かる。 


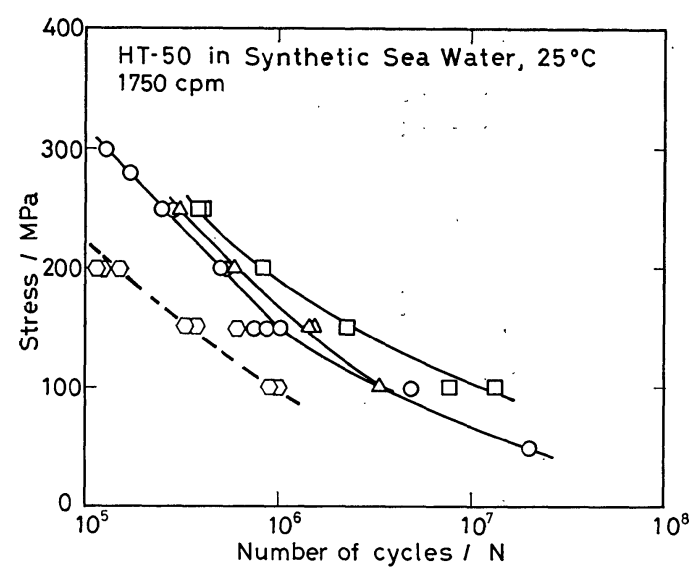

Fig. 11 S-N curves of HT-50 steel in synthetic sea water. The broken line shows the number of cycles corresponding to the initiation of the main crack determined by the first indication of the current increase.

\section{2 腐食疲労における局部腐食の形態}

すでに述べたように腐食疲労に沶いて，亀裂開口部よ り大きなアノード電流が流出するのではなく, Fig. 9 に 示したような腐食生成物の下に多数存在する孔食より多 くのアノード電流が発生している。このような孔食は繰 り返し荷重によりとの活性が維持され, さらに時間の経 過とともにその数も增加すると考光られる。また，これ らの孔食の多くは微小亀裂の起点となっている。従って 腐食疲学亀裂は多数存在する微小龟裂のうち応力条件の 厳しいものが選択されて急速に進展するが, 孔食を起点 とする多数の微小亀裂も同時に進展し, さらにその数が 増加し続けるために, これら微小亀裂の存在する場所が, 部分アノード電流の多くを占めるものと考えられる。

Fig. 12 に腐食疲労中の部分電流の経時変化と表面の

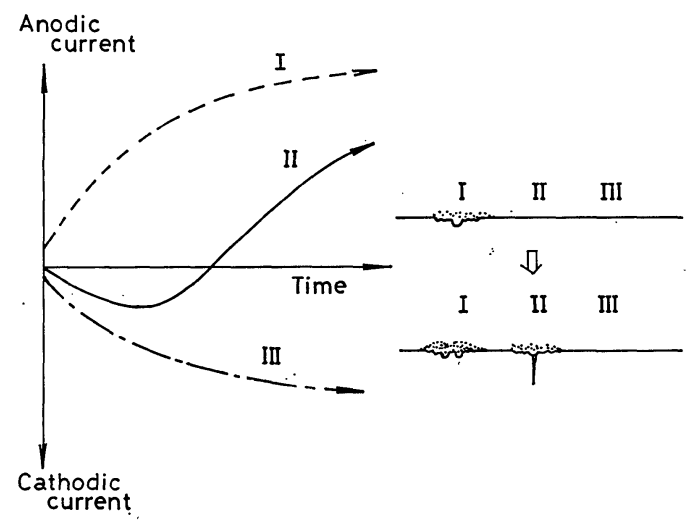

Fig. 12 Schematic drawing of the change in the local current density with time.

挙動との対応を模式的に示す。海水中のような中性環境 中にて高張力鋼は, アノード部分とカソード部分とがマ クロに分離し，アノード部分では, 鉄の溶解とともに水 酸化物の沈殿を生じ，孔食の発生をともなう。図中 I で 示したこのような部分では浸漬直後よりアノード電流は 增加し続ける。一方, II の部分では, はじめカソードで あった箇所が, 後に水酸化物の沈殿にともなら孔食の発 生のために応力集中場となり亀裂の進展する場所となっ ている。また，林のよらなアノードにならない部分では 他の部分でのアノードの増大, さらにはカソード領域の 面積減少にともないカソード電流密度は増大し続けてい る。

\section{3 腐食疲労における電位決定過程}

4.2 で述べたように, アノード部分は亀裂発生位置に 集中するのではなく, 試料表面の広い範囲に分布してい る。従って, 亀裂先端の溶解反応飞影響すると考えられ る電位は, 必ずしも亀裂部分によって決定されるのでは ない。Fig. 13 にアノード, カソード両反応による電位

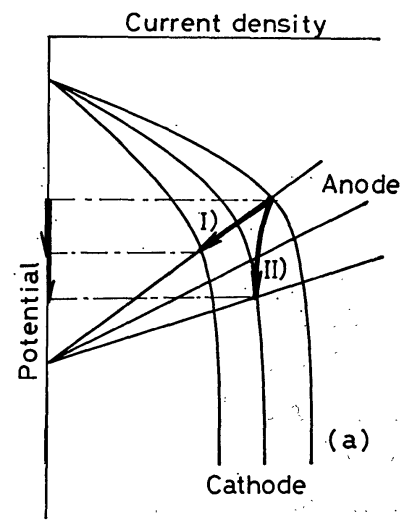

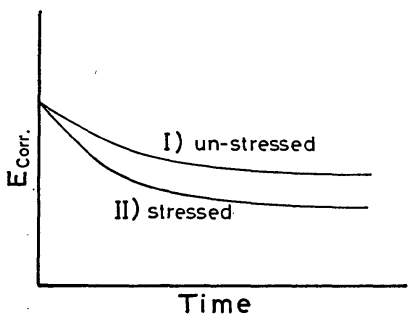

(b)

Fig. 13 Schematic drawing of the change in the corrosion potential, determined by both of anodic and cathodic processes. 
決定過程を模式的に示す。一般に，海水中での高張力鋼 の腐食は $\mathrm{Fe}^{2+}$ イオンの溶解であるアノード反応と, 酸 素還元によるカソード反応がカップルして電位を決定し ている。時間の経過とともに，腐食生成物の表面での沈 殿のためにカソード過程が抑制され Fig. 13 (a) 中の経 路 I）に示すように電位は卑な方向へ変化する。一方, 荷重が加わると腐食生成物の沈殿によるカソード過程の 抑制と同時に，繰り返し荷重が孔食底を活性化するため にアノード反応を促進し，さらに繰り返しひずみが表面 被膜を取り除くために沈殿被膜形成によるカソード過程 の抑制も抑学られ，その結果電位は Fig. 13 (a) の経路 II）のよらに変化するものと考光られる。すなわち, Fig. 13 (b) に示すように荷重を負荷した場合には荷重 のない場合より卑な電位を示す。すなわち，すでに述べ たように，低荷重の場合は活性な孔食が多数発生し，ま た亀裂進展中の荷重負荷時と停止時との電位の差がほと んぞ認められない。従って, 試料の腐食電位は亀裂部分 でのアノード溶解のみではなく，多数発生している孔食 のアノード溶解反応と表面全域での酸素カソード還元反 応によって決定されていると考光られる。一方, 高荷重 の場合は，主亀裂からのアノード電流が明確に観察さ れ，腐食電位も卑な值をとることより，亀裂部分のア， 一ド電流が電位決定に大きく寄与していると考兄られ る。ところで, 本研究では, 走查振動電極による腐食疲 労試片の電流分布の測定は疲労試験機の運転を停止した 除荷時に行っているため, 応力による溶解活性化の効果 は必ずしも明らかでない。従って以上のことについては 繰り返し荷重負荷時の in-situ な電流分布の測定が必要 とされ，このことは今後の課題である。

本報告で取り上げた海水中での低合金鋼の場合のよう な，マクロな腐食生成物を形成する系では，亀裂部分の みによって全体の電気化学反応が決定されているのでは ない。しかし，ステンレス鋼のような被膜の安定な系て は水酸化物の沈殿による孔食の発生は起こり難いので, 亀裂発生位置よりのアノード電流が観測された ${ }^{12)}$ 。今後 このような系についての検討に興味が持たれる。

\section{5. 結言}

1）局部腐食の進行している金属表面上の電流密度分
布を測定しらる走査振動電極システムを開発し，これを 人工海水中に批活高張力鋼の腐食疲労試験に 適用し た。

2）走査振動電極システムによって，局部腐食の起こ っている金属平面上の局部アノード，カソード電流の分 布及び強度を測定し 3 次元グラフとして表示することが できた。

3）高張力鋼の人工海水中での腐食疲労に打いては, 亀裂部分より集中してアノード電流が発生するのではな く，表面に多数分布する孔食の存在する部分がアノード となる。これら孔食を起点とする多数の微小クラックが 観察された。

本研究に要した費用の一部は昭和 60 年度科学研究費 補助金総合研究 (A) (研究課題番号：59350006) の補助 を受けた。記して謝意を表する。

(Received May 14, 1986)

\section{文献}

1）江原隆一郎：日本鉄鋼協会，第 84, 85 回 西山記 念技術講座テキスト, 173 (1982).

2) 柴田俊夫, 藤本慎司：第 32 回腐食防食討論会予 稿集, 73 (1985).

3) H.S. Isaacs and Brijesh Vyas: "Electrochemical Corrosion Testing”, ASTM STP 727, 3 (1981).

4）金児紘征，泰松 斉：日本金属学会誌，42，381 (1978).

5) L. F. Jaffe and R. Nuccitelli: J. Cell Biology, 63, 614 (1974).

6) Y. Ishikawa and H. S. Isaacs: Presented at Conf. on Corros. and Exploitation of Alluminium Alloys, Cranfield, England (April, 1983).

7) 石川雄一, H.S. Isaacs：防食技術， 33, 147 (1984)

8）藤本慎司，柴田俊夫：腐食防食協会，第 59 回腐 食防食シンポジウム資料, 81 (1985).

9）柴田俊夫，北岡一夫：腐食防食 ' 85,225 (1985).

10）江原隆一郎：腐食防食 '85, 221 (1985).

11） 10）の文献 23); R. N. Parkins： Presented at Metals Society Meeting on Corrosion Fatigue, Newcastle (1978).

12）柴田俊夫, 藤本慎司：未発表. 